\title{
Yield and Digestibility of Old World Bluestem Grasses as Affected by Cultivar, Plant Part, and Maturity
}

\author{
S. M. DABO, C. M. TALIAFERRO, S. W. COLEMAN, F. P. HORN, AND P. L. CLAYPOOL
}

\section{Abstract}

Old World bluestems (Bothriochloa spp.) have been used in the U.S. for over 60 years but few data are available on effects of management or cultivar differences for forage yield and quality. Field experiments were conducted on a Kirkland silt loam (Uderic Paleustoll) soil for 2 years (1982-83), in order to assess the yield and quality of 4 such cultivars as affected by maturation and plant part. The experimental design was a split-split plot, in a randomized complete block, with 4 replications, 4 cultivars ('Caucasian', 'Ganada', 'Plains', 'WW Spar'), 10 harvest dates, and 3 plant parts (whole plant, stem, and leaf). Cultivars were main plots; harvest dates and plant parts were sub and sub-sub plots, respectively. Response variables were dry matter yield (DMY), in vitro dry matter disappearance (IVDMD), leaf to stem ratio (L/S), and in vitro digestible dry matter yleld (IVDDMY). Ganada consistently had the lowest leaf, stem, and whole plant DMY and IVDDMY. Caucasian had higher leaf, stem, and whole plant DMY and IVDDMY than Plains and WW-Spar in 1983, but the DMY and IVDDMY of these cultivars were similar in 1982. Quadratic and linear equations were satisfactorily fit to the DMY and IVDDMY data in 1982 and 1983, respectively. The IVDMD in whole plant samples decreased at average rates of 4.2 and $5.5 \mathrm{~g} \mathrm{~kg} \mathrm{ha}^{-1}$ daily in 1982 and 1983, respectively, during harvest week one. Among cultivars, Caucasian had the highest rate of decline and Ganada the lowest. The decline was quadratic in nature and faster in stem fractions. Cultivar IVDMD differences were consistent over plant parts. Ganada and Caucasian had the highest and lowest IVDMD concentrations, respectively. Plains and WW-Spar had IVDMD values of similar magnitude and intermediate to those of Ganada and Caucasian. Cultivar leaf to stem ratios were similar in 1982 but different in 1983 with Plains and Caucasian having higher L/S ratios than Ganada and WW-Spar. For these cultivars leafiness was a poor indicator of digestibility.

Key Words: 'Ganada', 'WW-Spar', 'Plains', 'Caucasian', plant morphology, dry matter yield, IVDMD, IVDDM, leaf to stem ratio

Old World bluestems (Bothriochloa spp.) are highly apomictic, perennial, warm-season, bunchgrasses of Eurasian origin (Harlan and Chheda 1963, Harlan et al. 1964, and Taliaferro and Harlan 1973). These grasses are known for their apparent superiority to American forms (Andropogon spp.) with respect to production, quality, persistence under grazing, and ability to respond to high fertility levels. They are also potentially important as erosion control and reclamation grasses for millions of hectares of depleted range and marginal farmlands in the southern Great Plains.

Despite extensive use of Old World bluestems (OWB) by livestock producers in the southern Great Plains, few data are available on their yield and quality trends, and on leaf and stem contributions to these parameters throughout the growing season.

Comparative forage yield tests in Oklahoma have shown 'Plains' bluestem [Bothriochloa ischaemum (L.) King. var. ischaemum] to

\footnotetext{
Senior, second, and fifth authors are former research assistant, Department of Agronomy, and professors, Department of Agronomy and Statistics, respectively, Oklahoma State University, Stillwater 74078. Third and fourth authors are research animal scientists, Livestock and Forage Research Laboratory, USDA-ARS, El Reno, Okla. 73036.

The authors wish to thank Dr. D.M. Ahring, research agronomist, USDA-ARS, Plant Science Research Laboratory, Stillwater, Okla., and Dr. R. D. Pieper, Department of Animal and Range Science, New Mexico State University, for reviewing this manuscript and providing thoughtful suggestions.

Manuscript accepted 7 July 1986.
}

be less productive than 'Caucasian' bluestem [ $B$. caucasica (Trin.) C.E. Hubbard] but equal in persistence (Taliaferro et al. 1972). Dalrymple et al. (1980) reported preliminary yield test results of commercially available $O W B$ cultivars. The Caucasian and Plains cultivars had the highest yields (about $5,712 \mathrm{~kg} \mathrm{ha}^{-1}$ ) and 'Ganada' [B. ischaemum (L.) Keng. var. ischaemum] the lowest (about 5,176 $\mathrm{kg} \mathrm{ha}^{-1}$ ).

Taliaferro et al. (1972) found that the in vitro dry matter disappearance (IVDMD) of the Plains cultivar was higher than that of Caucasian (49.3 vs. $45.4 \%$ ). The IVDMD of both cultivars decreased as the growing season advanced. Horn and Taliaferro (1979), studied seasonal changes in IVDMD values of hay from 5 OWB cultivars including Plains and Caucasian. A downward trend in IVDMD occurred as the season progressed though the total decline was not great. The lowest IVDMD values were reached in August.

The nutritional value of forage may be underestimated by analyzing only whole plant samples because livestock seldom consume whole plants, but rather selectively graze individual parts (Kalmbacher 1983). The parts of a plant (inflorescence, leaf blade, leaf sheath, and culm) differ in quality (Kalmbacher 1983). Generally, the nutritive value of leaves is superior to that of stems (Minson et al. 1960, Minson et al. 1964, Terry and Tilley 1964, and Kalmbacher 1983). In vitro studies by Minson et al. $(1960,1964)$ with ryegrasses, fescue, timothy and cocksfoot grasses separated into leaf lamina, leaf sheath, stem, inflorescence, and dead material, indicated that digestibility of the leaf lamina fraction decreased $0.10 \%$ per day with advancing maturity. Leaf sheaths and stem fractions decreased more rapidly than the lamina with increasing maturity $(0.40 \%$ and $0.70 \%$ per day, respectively). Yet, stem fractions were more digestible than leaf fractions in immature stages of growth. Similar results were reported by Mowat. et al. (1965).

The objectives of this study were to: (a) characterize the forage yield and quality differences of whole plant and component plant parts of 4 OWB cultivars as affected by stage of maturity, and (b) ascertain the relationships between yield patterns and IVDMD.

\section{Materials and Methods}

This study was conducted in 1982 and 1983 on the Agronomy Research Station, Stillwater, Okla. The soil type was a Kirkland silt loam (Uderic Paleustoll). The field plot design was a split-split plot, in a randomized complete block design with 4 replications. The 4 OWB cultivars were Plains, Caucasian, Ganada, and "WWSpar' [B. ischaemum (L.) Keng var. ischaemum]. Plots were $6^{8} .6$ $\mathrm{m}$, each consisting of 5 rows spaced $15 \mathrm{~cm}$ apart. The test was seeded 28 July 1980.

The nursery was prepared for study by cutting the experimental area to a uniform height (staged) of about $1.00 \mathrm{~cm}, 22 \mathrm{June} 1982$ and 25 May 1983. The plots were fertilized with $120 \mathrm{~kg} \mathrm{~N} \mathrm{ha}^{-1}$ soon after staging. Plots were then divided into ten $0.5 \mathrm{~m}^{2}$ subplots. During the experiment, the nursery was irrigated regularly to maintain abundant soil moisture. Prior to harvest, plots were trimmed to eliminate border effects. Harvesting was started 3 weeks after staging; and continued at weekly intervals for 10 weeks. Harvest dates (1 through 10) were randomly assigned to subplots. Plants in subplots were clipped at $1.3 \mathrm{~cm}$ from ground level. Subplot total green weight was recorded for yield measurements and 2 subsamples were taken. One subsample was oven dried at $65^{\circ}$ $\mathrm{C}$ for $\mathbf{7 d a y s}$ and used to convert subplot green yield weights to dry 
matter yields (DMY). The second subsample was frozen and later separated into leaf, stem, and head (inflorescence) components. Leaves consisted of blades broken off at the sheath. After separation, the respective plant parts were dried in a forced draft oven at $65^{\circ} \mathrm{C}$ for 7 days. Dry matter weights of leaves, stems, and inflorescences were used to estimate the percentage of each plant part in the subplot total dry weight. All dried samples were then ground first through a 5-mm screen in a Wiley Mill and through a 1-mm screen in a UDY Cyclone Mill. This resulted in 20 to $30 \mathrm{~g}$ of ground forage which was used to determine forage IVDMD. The IVDMD was determined for each dried sample with the exception of inflorescences.

IVDMD was measured by near infrared reflectance (NIRR) spectroscopy using a monochromator. Sixty-four scans of each sample with monochromatic light in the near infrared region, from 1,100 to $2,500 \mathrm{~nm}$, were averaged and stored on a Digital Equipment Corporation mini-computer PDP 11/23. Seven hundred data points at $2.0-\mathrm{nm}$ intervals were recorded for each sample. The monochromator was calibrated with IVDMD data from the laboratory analysis of 480 forage samples (50\% of all samples including stems, leaves, and whole plants). The 480 samples were drawn from 2 randomly selected replications. Percent IVDMD for the laboratory analysis was determined in triplicate using a modified Tilley and Terry technique (Monson et al. 1969). Calibration of the monochromator was achieved using the computer software developed at Pennsylvania State University (Shenk et al. 1977). The software combined NIRR reflectance data with the laboratory analyses, performed the necessary mathematical transformations $(\log 1 / R, 1$ st and 2 nd derivatives), and used a modified stepwise linear regression procedure to find the wavelengths most useful for predicting the desired quality parameter. Seven calibration equations resulted and included 1 to 7 wavelengths and their regression coefficients for predicting forage quality characters. On the basis of the R-square, bias, and standard error of prediction statistics, an equation was chosen to predict the IVDMD from the reflectance spectra of the remaining samples.

An overall statistical analysis was first conducted on each response variable using ANOVA procedures for a split-split plot arrangement. Data were analyzed within year and by plant part to assess cultivar differences and effects of harvest dates. The least significant difference test of treatment means backed by significant F-test was used to determine differences among cultivars and maturity stages (Steel and Torrie 1960). Orthogonal polynominals partitioned harvest dates and harvest dates $X$ year sum-of-squares into linear, quadratic, and deviation from quadratic components. Yield results were correlated with whole plant IVDMD values to ascertain the significance of their relationship. The in vitro digestible dry matter yield (IVDDMY) was computed as the product of DMY (kg ha $\left.{ }^{-1}\right)$ in IVDMD ( $\left.\mathrm{g} \mathrm{hg}^{-1}\right)$ at each harvest. Leaf to stem ratio $(L / S)$ was calculated and both $L / S$ and IVDDMY data were analyzed by the same statistical procedures as stated above.

\section{Results and Discussion}

Because of significant first, second and third order interactions involving cultivars, harvest dates, years, and plant parts for yield and IVDMD, results are reported by year and plant part.

\section{Dry Matter Yields}

Differences in whole plant, leaf, and stem DMY due to cultivar and harvest date were highly significant $(P<.01)$ each year. The significant $(P<.05)$ cultivar $\times$ harvest date interactions in 1982 were caused more by differences in magnitude of response, than by changes in cultivar rank. Ganada had the lowest $(P<.05)$ DMY of whole plant and component parts both years (Fig. 1). Caucasian consistently had higher $(P<.05)$ leaf, stem, and whole plant DMY than Plains and WW-Spar in 1983, but the DMY of these cultivars was similar in 1982. In 1983, the whole plant DMY of Caucasian was about $17 \%$ more than Plains. For the same year, the whole plant DMY of Ganada was 16 and $20 \%$ lower than that of Plains and WW-Spar, respectively. In 1982, the DMY of Ganada was about $30 \%$ lower than the average DMY of Plains, Caucasian, and WW-Spar. These results agree with previous studies (Taliaferro et al. 1972, Dalrymple et al. 1980, and Sims and Dewald 1982) but disagree with others (Dalrymple et al. 1984).

The DMY of all cultivars increased significantly $(P<.01)$ with advancing maturity due to accumulated growth (Fig. 1). The data were satisfactorily fit to second order polynomial equations in 1982 and to linear equations in 1983. This inconsistency in DMY trends between years was likely the result of environmental differences on growth.

The linear equations in 1983 revealed weekly mean DMY increases of 393,41 , and $327 \mathrm{~kg} \mathrm{ha}^{-1}$ for whole plants, leaves, and stems, respectively. In 1982, the derivative of quadratic equations revealed that whole plant DMY increased 700,440 , and $182 \mathrm{~kg} \mathrm{ha}^{-1}$ weekly prior to harvest dates 2,5 , and 8 , respectively. Similarly, weekly mean stem DMY increases were 446,320 and $195 \mathrm{~kg} \mathrm{ha}^{-1}$, respectively. The DMY increases in leaf fractions were less in magnitude as compared to whole plant and stems. Mean leaf DMY increases were 260 and $38 \mathrm{~kg} \mathrm{ha}^{-1}$ per week prior to harvest dates 2 and 6 , respectively, in 1982 . Ganada had lower rates of increase than the other cultivars both years. Caucasian had the highest rates of increase in 1983 but not in 1982 . The $R^{2}$ values obtained for leaves were smaller than those for stems, indicating that maturation contributed more to stem DM yield (data not presented).

\section{In Vitro Dry Matter Disappearance}

There were significant differences in the IVDMD of whole plants, leaves, and stems due to cultivar and harvest dates both years. The cultivar $X$ harvest date interactions for the IVDMD of whole plants, leaves, and stems were significant $(P<.01)$ in 1982. The same interaction was significant for the stem fraction only in 1983.

Ganada was consistently higher than other cultivars in IVDMD, while Caucasian tended to have the lowest IVDMD (Fig. 2). In 1983 , Caucasian stems were higher $(P<.05)$ in IVDMD than those of Plains and WW-Spar especially after harvest date 3 . The IVDMD values of Plains and WW-Spar were similar both years and intermediate to those of Ganada and Caucasian (Fig. 2). Cultivar differences were more noticeable in leaves than in whole plants or stems (Fig. 2). Differences obtained between Plains and Caucasian agree with previous results (Horn and Taliaferro 1979). The low IVDMD values of Caucasian were probably due in part to

Table 1. In vitro digestible dry matter yield of whole plant, leaf, and stem samples of four old world bluestem cultivars (means of 10 harvest dates).

\begin{tabular}{|c|c|c|c|c|c|c|}
\hline \multirow[b]{2}{*}{ Cultivar } & \multicolumn{2}{|c|}{ Whole Plant } & \multicolumn{2}{|c|}{ Leaf } & \multicolumn{2}{|c|}{ Stem } \\
\hline & 1982 & 1983 & 1982 & 1983 & 1982 & 1983 \\
\hline $\begin{array}{l}\text { Plains } \\
\text { Caucasian } \\
\text { Ganada } \\
\text { WW-Spar }\end{array}$ & $\begin{array}{l}1407 a^{1} \\
1277 a^{2} \\
1007 b^{-} \\
1380 a\end{array}$ & $\begin{array}{l}1294 \mathrm{~b} \\
1499 \mathrm{a} \\
1168 \mathrm{~b} \\
1341 \mathrm{ab}\end{array}$ & $\begin{array}{l}-\mathrm{kg} \mathrm{ha} \mathrm{h}^{-1} \\
638 \mathrm{a}(45)^{2} \\
468 \mathrm{~b}(37) \\
437 \mathrm{~b}(43) \\
566 \mathrm{ab}(41)\end{array}$ & $\begin{array}{l}473 \text { a }(37) \\
511 \text { ab (34) } \\
325 \text { c }(28) \\
379 \text { ac (28) }\end{array}$ & $\begin{array}{l}766 \mathrm{a}(54) \\
722 \mathrm{a}(60) \\
564 \mathrm{~b}(56) \\
786 \mathrm{a}(57)\end{array}$ & 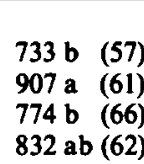 \\
\hline
\end{tabular}

IValues within a column followed by the same letter are not significantly different $(P>.05)$ as indicated by the L.S.D: test.

${ }_{2}^{2}$ Percentage contribution to the whole plant IVDDMY. 

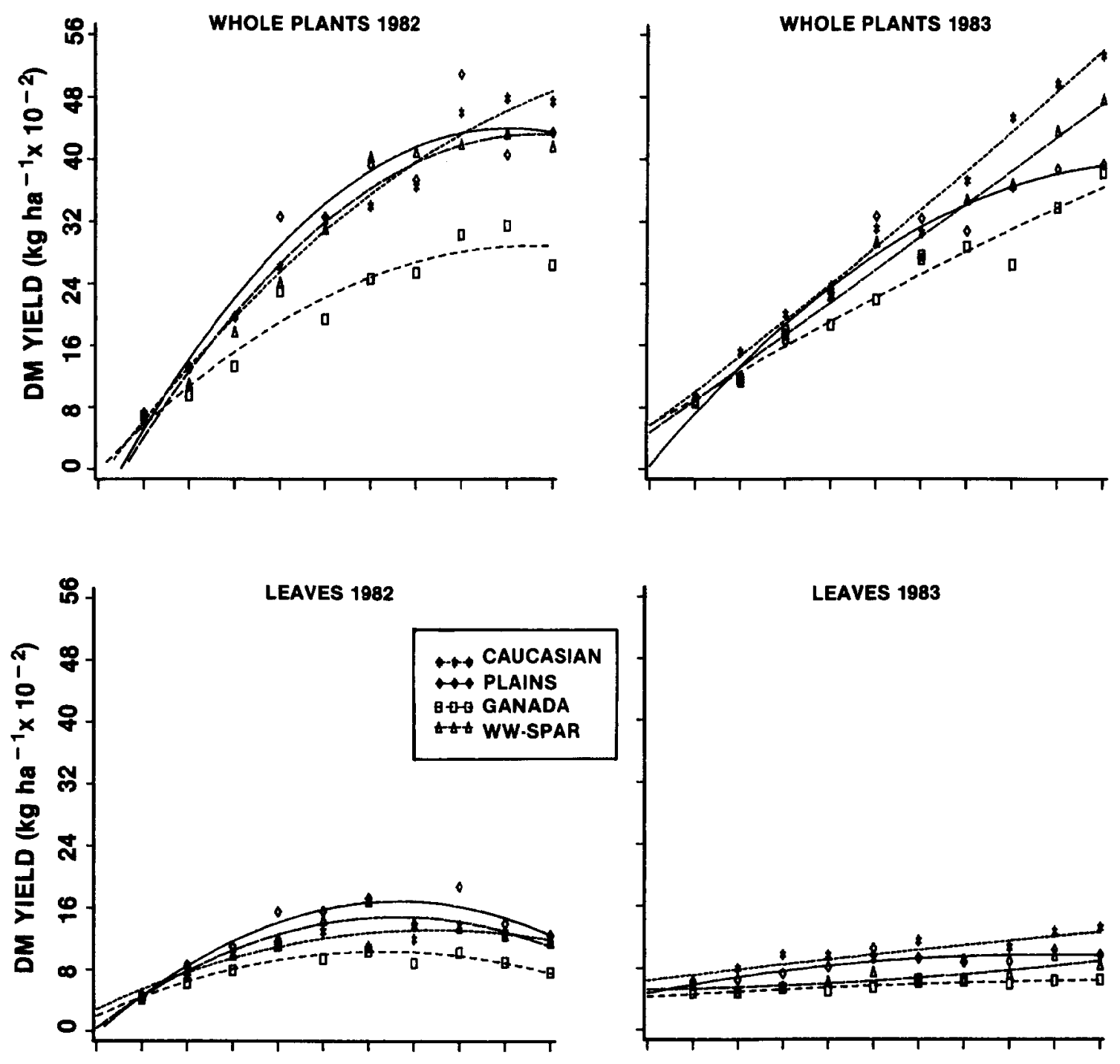

LEAVES 1983
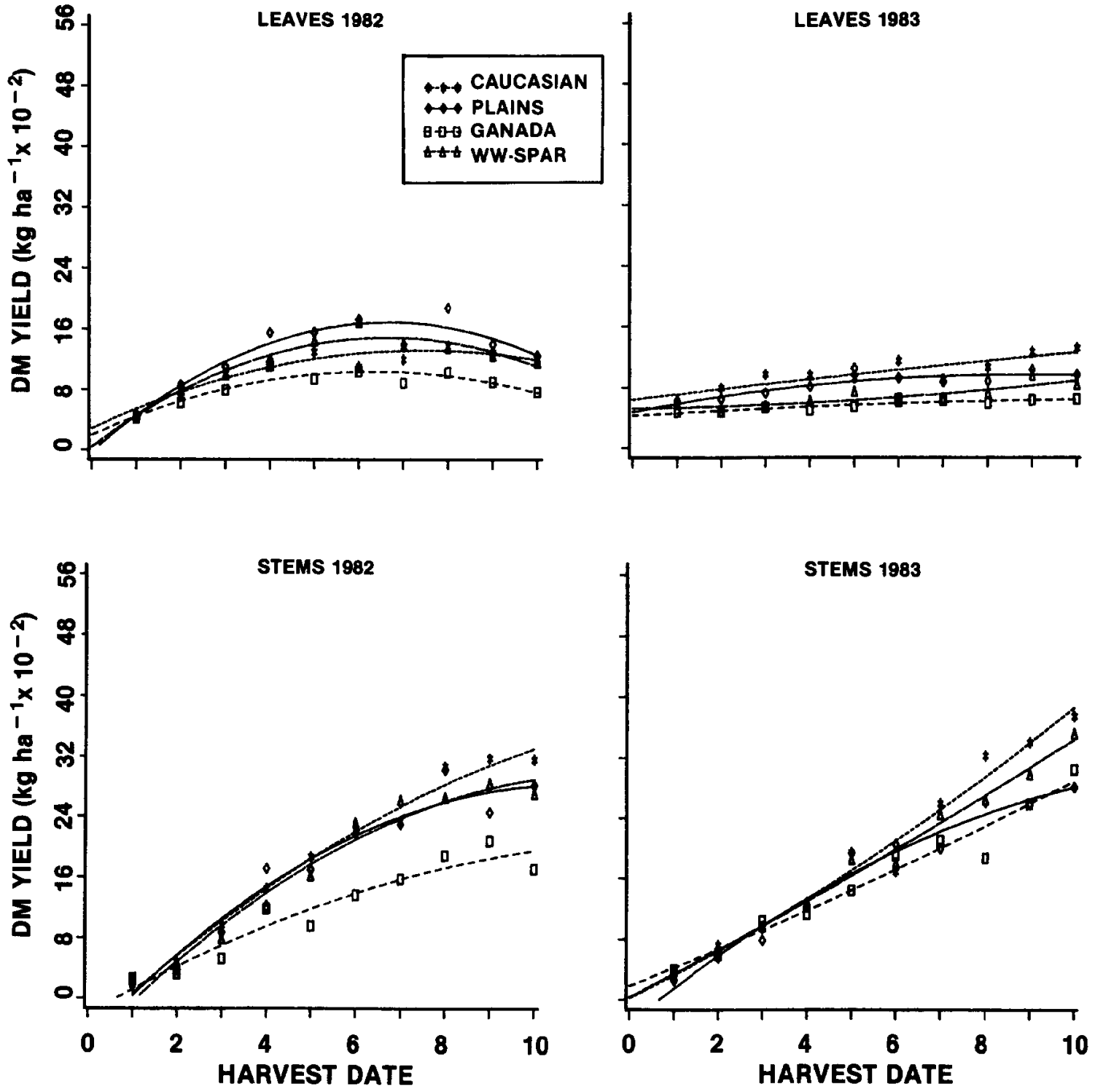

Fig. 1. Dry matter (DM) yields of whole plants, leaves, and stems of 4 Old World bluestem cultivars at 10 harvest dates. 

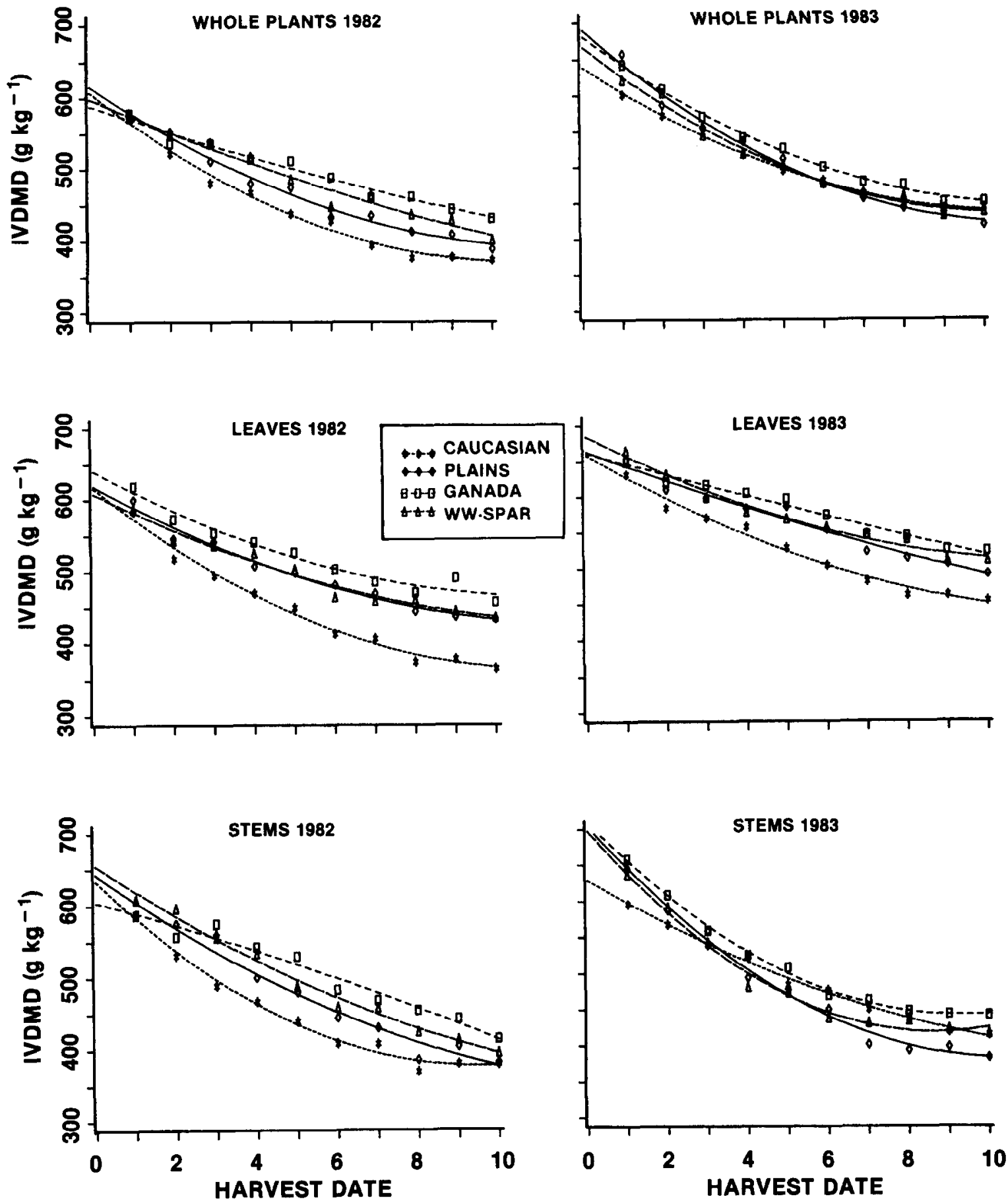

Fig. 2. In vitro dry matter disappearance (IVDMD) of whole plants, leaves, and stems of 4 Old World bluestem cultivars at 10 harvest dates.

its rapid growth rate and high DMY as reported by Horn and Jackson (1979).

The mean IVDMD of all cultivars and all plant parts decreased significantly $(P<.01)$ with maturation (Fig. 2). Orthogonal polynomials indicated that the data satisfactorily fit quadratic equations but different quadratic equations were required for each year.

The rate of IVDMD decline was generally faster in Caucasian and slower in Ganada, particularly in 1982, with respective rates ranging from 5.8 to $3.2 \mathrm{~g} \mathrm{~kg}^{-1}$ daily in whole plants during harvest week one. For the same period and plant part, the mean IVDMD of all cultivars decreased at rates of 4.2 and $5.5 \mathrm{~g} \mathrm{~kg}^{-1}$ daily in 1982 and 1983, respectively. These rates of decline are comparable to those reported by Pritchard et al. (1963) and Voigt et al. (1981). The IVDMD values of immature stems were similar to corresponding values of leaves (Fig. 2). However, the rate of decline of IVDMD with advancing maturity was greater in stems than in leaves for each cultivar except Ganada in 1982.

Ganada whole plant Mean IVDMD was 8,5 , and $3 \%$ higher than of Caucasian, Plains, and WW-Spar (data not presented). This could translate into substantial animal performance differences between cultivars. For example, 'Coastal'bermudagrass [ $C y n o d o n$ 
Table 2. Simple correlations between dry matter yields and in vitro dry matter disappearance of whole plants, leaves, and stems of four old world bluestem cultivars (data averaged over sampling period and years).

\begin{tabular}{lccc}
\hline & \multicolumn{3}{c}{ Plant Part } \\
\cline { 2 - 4 } Cultivar & Whole plants & Leaves & Stems \\
\hline Plains & $-.82^{* *}$ & $-.59^{* *}$ & $-.85^{* *}$ \\
Caucasian & $-.76^{* *}$ & $-.62^{* *}$ & $-.75^{* *}$ \\
Ganada & $-.72^{* *}$ & $-.44^{* *}$ & $-.71^{* *}$ \\
WW-Spar & $-.83^{* *}$ & $-.51^{* *}$ & $-.83^{* *}$ \\
\hline
\end{tabular}

$* * 0<01$

dactylon (L.) Pers], 'Pensacola' bahiagrass (Paspalum notatum var. saurae parodi) and 'Coastcross-1' bermudagrass were compared for average daily gain (ADG) and IVDMD (Chapman et al. 1972). The ADG over all stocking rates on Coastcross-1 bermudagrass pastures were $50 \%$ higher than those for Coastal bermudagrass. The authors concluded that the majority of that difference was due to the greater apparent digestibility $(12 \%)$ and/or intake of Coastcross- 1 bermudagrass.

\section{In Vitro Digestible Dry Matter Yield}

Differences in IVDDMY due to harvest date were significant $(P<.01)$ but there were no significant $(P>.05)$ cultivar $\times$ harvest date interactions. Cultivar differences were highly significant $(P<01)$. Over all harvest dates Caucasian consistently had higher $(P<.01)$ IVDDMY of whole plant, leaves, and stems than Ganada (Table 1). There was no difference $(P>.05)$ in the IVDDMY of Plains, WW-Spar, and Caucasian in 1982 or Plains, WW-Spar and Ganada in 1983. The effect of harvest date on IVDDMY was similar to that discussed above for DM yield. The data satisfactorily fit second and first order polynomial equations in 1982 and 1983 , respectively.

\section{Leaf to Stem Ratio}

Differences in $L / S$ ratios due to cultivar, and cultivar $X$ harvest date interactions were highly significant in $1983(P<.01)$ but nonsignificant in $1982(P>.05)$. Plains and Caucasian had similar $(P>.05)$ but higher $L / S$ ratios than Ganada and WW-Spar $(P>.05)$ in 1983 (Table 3). Leafiness was a poor indicator of digestibility differences as the less digestible cultivars contained the most leaves. Leaf to stem ratios for the respective cultivars decreased significantly $(P<.01)$ with advancing maturity (Table 3$)$ and generally in a quadratic manner.

Significant negative correlations were obtained between IVDMD DMY of whole plant and component parts in all cultivars (Table 2). Among cultivars, Ganada had the lowest correlations for whole plant, leaves, and stems. Plains and WW-Spar had the highest correlations for stems while Caucasian correlations were highest for leaves. Correlations were higher for stems than for leaves. This inverse relationship between DMY accumulation and IVDMD is consistent with reports for many other forage species.

In summary, characteristics such as DMY, IVDMD, and their rates of change dictated the IVDDMY levels of the cultivars at any given harvest date. The cultivars under investigation varied significantly with regard to the above parameters. The cultivar with the highest IVDMD (Ganada) had generally the lowest DMY and IVDDMY. While some yield and quality differences among cultivars were obvious (Caucasian vs. Ganada) others were less conclusive and need to be confirmed. The Plains and WW-Spar cultivars were generally similar for the above parameters. Yields of whole plant and component parts over the 10-week period correlated negatively with IVDMD, suggesting a rapid decline in forage quality with advancing maturity. Leafiness among cultivars was a poor indicator of digestibility differences.

\section{Literature Cited}

Chapman, H.D., W.H. Marchant, P.R. Utley, R.E. Hellwig, and W.G. Monson. 1972. Performance of steers on Pensacola bahiagrass, Coastal bermudagrass and Coastcross-1 bermudagrass pastures and pellets. J. Anim. Sci. 34:373-378.

Dalrymple, R.L., J. Rogers, and L. Timberlake. 1980. Asiatic bluestems. Noble Found. Agr. Div. Pub. AB-80.

Dalrymple, R.L., J. Rogers and L. Timberlake. 1984. Old World Bluestem comparison. Noble Found. Agr. Div. Pub. AB-84.

Harland, J.R., M.H. Brooks, D.S. Borgaonkar, and J.M.J. de Wet. 1964. Nature and inheritance of apomixis in Bothriochloa and Dicanthium. Bot. Gaz. 125:41-46.

Harlan, J.R., and H.R. Chheda. 1963. Studies on the origin of Caucasian bluestem, Bothriochloa Caucasica (Trin.) C.E. Hubbard. Crop Sci. 3:37-39.

Horn, F.P., and W. Jackson. 1979. Digestibility of 5 "Old World Bluestems" hays. Okla. Agr. Exp. Sta. Anim. Sci. Res. Rep. MP-104.

Horn, F.P., and C.M. Taliaferro. 1979. Seasonal changes in the nutritive value of 5 "Old World Bluestems" hays. Okla. Agr. Exp. Sta. Anim. Sci. Res. Rep. MP-104.

Kalmbacher, R.S. 1983. Distribution of dry matter and chemical constituents in plant parts of 4 Florida native grasses. J. Range Manage. 36:298-301.

Minson, D.J., C.E. Harris, W.F. Raymond, and R. Milford. 1964. The digestibility and voluntary intake of $S 22$ ryegrass, $H 1$ ryegrass, $S 170$ tall feccue, S48 timothy, S215 meadow fescue and germinal cocksfoot. J. Brit. Grassl. Soc. 19:298-305.

Minson, D.J., W.F. Raymond, and C.E. Harris. 1960. Studies on the digestibility of herbage. VIII. The digestibility of S37 cocksfoot, 523 ryegrass and S24 ryegrass. J. Brit. Grassl. Soc. 15:174-180.

Monson, W.G., R.S. Lowrey, and I. Forbes, Jr. 1969. In Vitro bag vs. 2-stage ln Vitro digestion: Comparison of 2 techniques estimating dry matter digestibility of forages. Agron. J. 61:587-589.

Table 3. Leaf to stem ratios of four old world bluestem cultivars at ten harvest dates during 2 years.

\begin{tabular}{|c|c|c|c|c|c|c|c|c|}
\hline \multirow{2}{*}{$\begin{array}{l}\text { Harvest } \\
\text { date }\end{array}$} & \multicolumn{4}{|c|}{19821} & \multicolumn{4}{|c|}{19832} \\
\hline & Plains & Caucasian & Ganada & WW-Spar & Plains & Caucasian & Ganada & WW-Spar \\
\hline 1 & 2.37 & 2.58 & 1.63 & 2.09 & 2.53 & 1.96 & 1.23 & 1.55 \\
\hline 2 & 2.17 & 1.85 & 1.94 & 2.70 & 1.20 & 1.11 & 0.83 & 0.80 \\
\hline 3 & 1.27 & 1.05 & 1.53 & 1.31 & 0.93 & 1.45 & 0.51 & 0.57 \\
\hline 4 & 0.92 & 0.81 & 1.01 & 0.99 & 0.65 & 0.87 & 0.47 & 0.48 \\
\hline 5 & 0.91 & 0.70 & 0.98 & 0.90 & 0.54 & 0.79 & 0.38 & 0.41 \\
\hline 6 & 0.81 & 0.51 & $\begin{array}{l}0.75 \\
0.75\end{array}$ & 0.72 & 0.45 & 0.47 & 0.34 & 0.34 \\
\hline 7 & 0.61 & 0.51 & 0.57 & 0.54 & 0.44 & 0.35 & 0.30 & 0.27 \\
\hline 8 & 0.61 & 0.45 & 0.56 & 0.53 & 0.33 & 0.33 & 0.36 & 0.27 \\
\hline 9 & 0.58 & 0.40 & 0.43 & 0.44 & 0.39 & 0.37 & 0.24 & 0.33 \\
\hline 10 & 0.45 & 0.39 & 0.45 & 0.43 & 0.34 & 0.36 & 0.21 & 0.24 \\
\hline$X$ & 1.07 & 0.92 & 0.99 & 1.06 & 0.78 & 0.81 & 0.49 & 0.53 \\
\hline
\end{tabular}

$15 \%$ L.S.D. for harvest date means $=0.12$.

$25 \%$ L.S.D. for harvest date means $=0.09$ 
Mowat, D.N., R.S. Fulkerson, W.E. Tossel, and J.E. Winch. 1965. the in vitro digestion and protein content of leaf and stem portions of forages. Can. J. Plant Sci. 45:321-331.

Pritchard, G.I., L.P. Folkins, and W.J. Pigden. 1963. The in vitro digestibility of whole grasses and their parts at progressive stages of maturity. Can. J. Plant Sci. 43:79-87.

Shenk, J.S., K.H. Norris, R.F. Barnes, and G.W. Fissel. 1977. Forage and feedstuff analysis with infrared reflectance spectrocomputer system. Proc. 13th Int. Grassl. Cong. Leipzig, G.D.R. Sims, P.L., and C.L. Dewald. 1982. Old World Bluestems and their forage potential for the Southern Great Plains. A review of early studies. USDA, ARS. Agr. Rev. and Manage. ARM-S-28.

Steel, R.G.D., and J.H. Torrie. 1960. Principles and procedures of statistics. McGraw-Hill Book Co., Inc. New York, N.Y.
Talinferro, C.M., and J.R. Harlan. 1973. Registration of Plains bluestem. Crop Sci. 13:13-580.

Taliaferro, C.M., J.R. Harlan, and W.L. Richardson. 1972. Plains Bluestem. Okla. Agr. Exp. Sta. Bull. B-699.

Terry, R.A., and J.M.A. Tilley. 1964. The digestibility of the leaves and stems of perennial ryegrass, cocksfoot, timothy, tall fescue and sainfoin as measured by an in vitro procedure. J. Brit. Grassl. Soc. 19:288-305.

Voigt, P.W., F.P. Horn, and C.L. Dewald. 1981. Forage quality response of 4 lovegrasses to stage, interval, and season of harvest. Agron. J. 73:877-884. 